\title{
A complication of thyroidectomy: Do not forget suture reaction
}

\author{
Burhan Hakan Kanat', Mehmet Buğra Bozan'1, Seyfi Emir', Fatih Mehmet Yazar', Fatih Erol', Özkan Alataș², \\ Hasan Baki Altınsoy ${ }^{2}$, Ali Aksu'
}

\begin{tabular}{|c|c|}
\hline \multirow[t]{5}{*}{ ABSTRACT } & $\begin{array}{l}\text { Objective: In this study, we aimed to present patients who have developed suture reaction and were treated in our } \\
\text { clinic following thyroidectomy operation. }\end{array}$ \\
\hline & $\begin{array}{l}\text { Material and Methods: Patients who had been treated for suture reaction following thyroidectomy between January } \\
2012 \text { and December } 2014 \text { were retrospectively evaluated. The patients were analyzed in terms of their age, gender, } \\
\text { duration of the symptoms, type of previous operation and treatment modality. }\end{array}$ \\
\hline & $\begin{array}{l}\text { Results: Between January } 2012 \text { and December } 2014,559 \text { thyroid/parathyroid operations were performed in our } \\
\text { clinic. A total of } 12 \text { patients were admitted with suture reaction within this period thus yielding a suture reaction } \\
\text { incidence of } 2.1 \% \text {. The mean age of these patients was } 42 \pm 7.65 \text { years, } 75 \% \text { of them were female while } 25 \% \text { of them } \\
\text { were male. The types of previous operations were bilateral total thyroidectomy in } 83.3 \% \text {, lobectomy in } 8.3 \% \text { and } \\
\text { near total thyroidectomy in } 8.3 \% \text { of the patients. The mean symptom duration was } 7.2 \pm 4.3(2-16) \text { months. Two } \\
\text { patients (16.7\%) underwent a second surgical operation for suture reaction, while } 10 \text { patients }(83.3 \%) \text { were treated } \\
\text { conservatively. None of the patients developed complications. }\end{array}$ \\
\hline & $\begin{array}{l}\text { Conclusion: One of the most common complications that develop after thyroidectomy is bleeding. Ligation must } \\
\text { be performed in order to prevent this complication. As it is known, surgical ligation with sutures may cause tissue } \\
\text { reaction. Sutures that are absorbable and have a low risk for reaction formation should be chosen if suturing is } \\
\text { preferred. }\end{array}$ \\
\hline & Keywords: Complication, fistula, sutures, thyroidectomy \\
\hline
\end{tabular}

Cite this paper as: Kanat BH, Bozan MB, Emir S, Yazar FM, Erol F, Alataş Ö, Altınsoy HB, Aksu A. A complication of thyroidectomy: Do not forget suture reaction. Turk J Surg 2017; 33(2): 58-61

'Department of General Surgery, Elazı̆ğ Training and Research Hospital, Elazı̆̆, Turkey 2Department of Radiology, Elazığ Training and Research Hospital, Elazı̆ğ, Turkey

Address for Correspondence Mehmet Buğra Bozan e-mail: bbozan@yahoo.com

Received: 28.04 .2015 Accepted: 04.10.2015

(c) Copyright 2017 by Turkish Surgical Association

\section{INTRODUCTION}

Thyroid surgery has historically been an adventure for surgeons until a century ago when several advances leading to modern surgery have been made, especially after Emil Theodor Kocher (Swiss doctor, medical researcher). In parallel with medical technologic developments and increased surgical experience, currently, surgery with low rates of mortality and morbidity has become a procedure of choice $(1,2)$.

Although there are many complications which may be encountered by thyroid surgeons, the most serious ones are recurrent laryngeal nerve injury, permanent hypoparathyroidism and postoperative bleeding. In thyroid surgery, re-operation is rarely needed in the presence of conditions such as early postoperative hematoma, recurrence, and those requiring completion thyroidectomy (3).

One of the most common complications seen after thyroidectomy is bleeding. Ligation must be performed for preventing this complication. Many surgeons prefer conventional suturing. As it is known, sutures are foreign bodies for the body and may cause a reaction, which is more common especially with non-absorbable sutures $(1,4,5)$.

In this study, our patients who were treated for suture reaction following thyroidectomy were presented.

\section{MATERIAL AND METHODS}

In this study, the patients who were treated for suture reaction following thyroidectomy in Elazığ Training and Research Hospital, Health Sciences University, Turkish Ministry of Health, General Surgery Inpatient/Outpatient Clinic between January 2012 and December 2014 were retrospectively evaluated. The study data were obtained from patient files, discharge reports, outpatient clinic records, personal registration forms of the authors and computer records. The patients with missing data and those who underwent thyroidectomy in another center were excluded. Informed consent was obtained from all individual participants included in the study. All procedures performed in studies involving human participants were in accordance with the ethical standards of the institutional and/or national research 


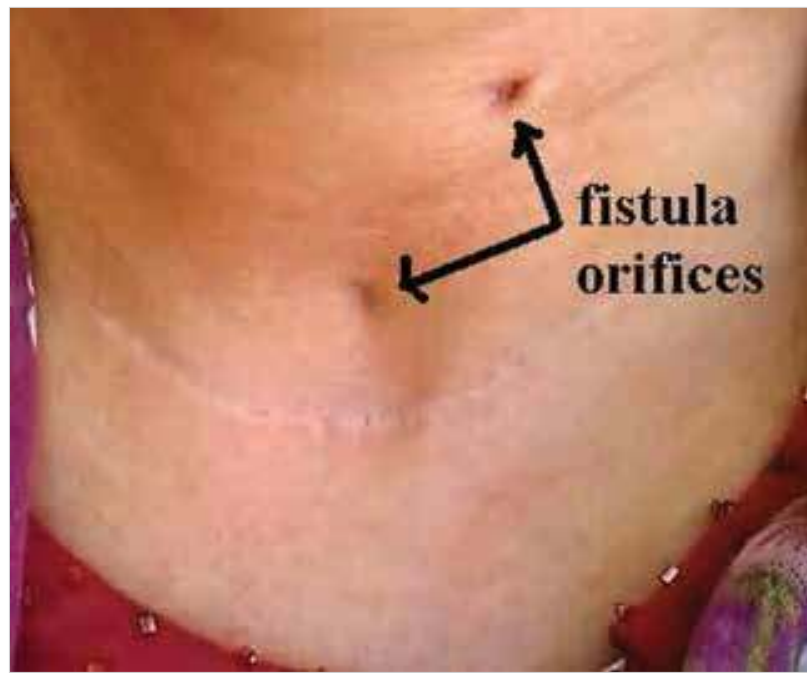

Figure 1. Patient with swelling and fistula in the neck

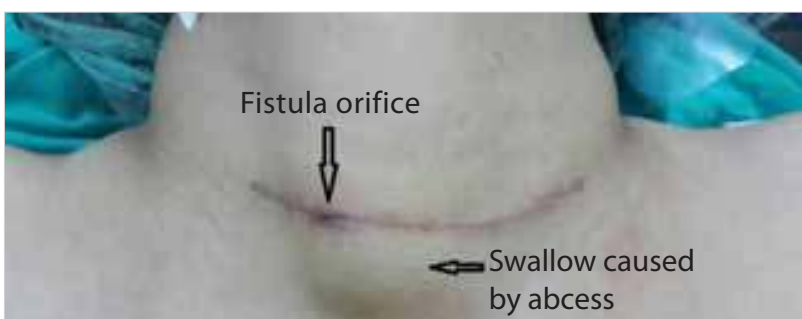

Figure 2. A tender fluctuating neck swelling under the incision scar

committee and with the 1964 Helsinki declaration and its later amendments or comparable ethical standards.

The diagnosis of suture reaction was made by physical examination of the patients with a history of thyroidectomy, and discharge, swelling and fistula in the neck (Figure 1). Imaging methods were used in the presence of suspicion. Conservative treatment was applied by opening the fistula tract and removing suture materials from this tract under local anesthesia, while surgical treatment was performed by excising the fistula tract and suture materials under general anesthesia.

The patients were analyzed in terms of their age, gender, duration of the symptoms, type of previous operation and treatment modality. The data analysis was performed using the Statistical Package for the Social Sciences for Windows version 12.0 (SPSS Inc.; Chicago, IL, USA).

\section{RESULTS}

Between January 2012 and December 2014, a total number of 544 thyroid operations, which consisted of bilateral total thyroidectomy in 501 , lobectomy in 18 , unilateral total-contralateral subtotal thyroidectomy in 6 , and near total thyroidectomy in 19 cases. Additionally, 15 parathyroid operations (concurrent with the thyroid operation in 7 cases) were performed.

During this period, a total of 14 patients were admitted with a diagnosis of suture reaction. Since one of these patients had

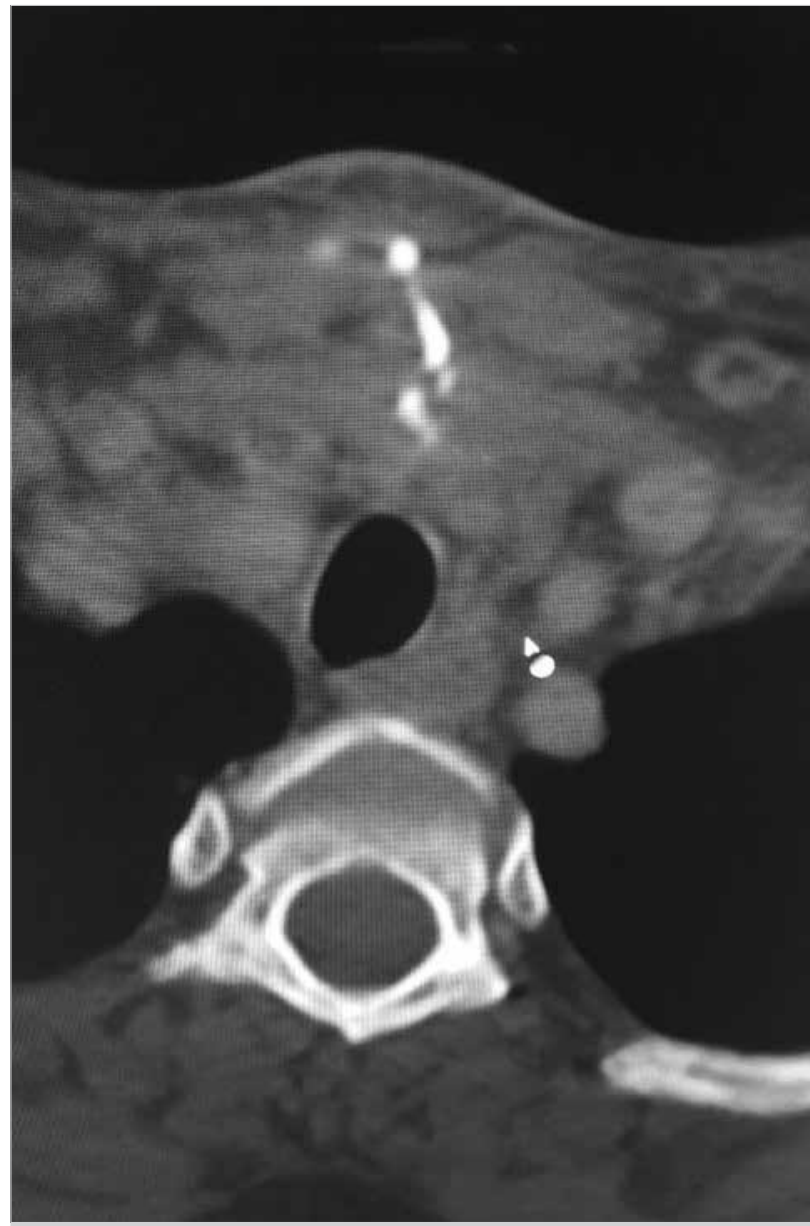

Figure 3. CT view of the fistula tracts extending from the incision line to the trachea

been operated in another health center and another one had been operated before January 2012, these two patients were excluded, and 12 patients were enrolled in the study. The incidence of suture reaction for the patients who were operated during this period was found to be $2.1 \%$.

The mean age of the patients was $42 \pm 7.65$ (24-51) years, $75 \%$ of them were female while $25 \%$ of them were male. The types of previous operations were bilateral total thyroidectomy in $83.3 \%$, lobectomy in $8.3 \%$ and near total thyroidectomy in $8.3 \%$ of the patients. The mean symptom duration was $7.2 \pm 4.3$ (2-16) months. Two patients (16.7\%) underwent a second surgical operation for suture reaction, while 10 patients (83.3\%) were treated conservatively. None of the patients developed postoperative complications. The patients except the ones who underwent surgery were not hospitalized.

In the physical examination of one of the patients treated by surgery, there was a tender neck swelling under the incision scar, which was fluctuating especially at the right (Figure 2). The patient was evaluated with the suspicion of hematoma, infection and foreign body reaction. The ultrasound examination revealed heterogeneity of $3 \mathrm{~cm}$ in size and edema between tissues. A computerized tomography (CT) was recommended by the department of radiology due to the presence of a suspicious hypoechoic line extending from the incisional line to the trachea. Contrast agent was given into the tract after cannulation of the tract while obtaining the CT scan. 


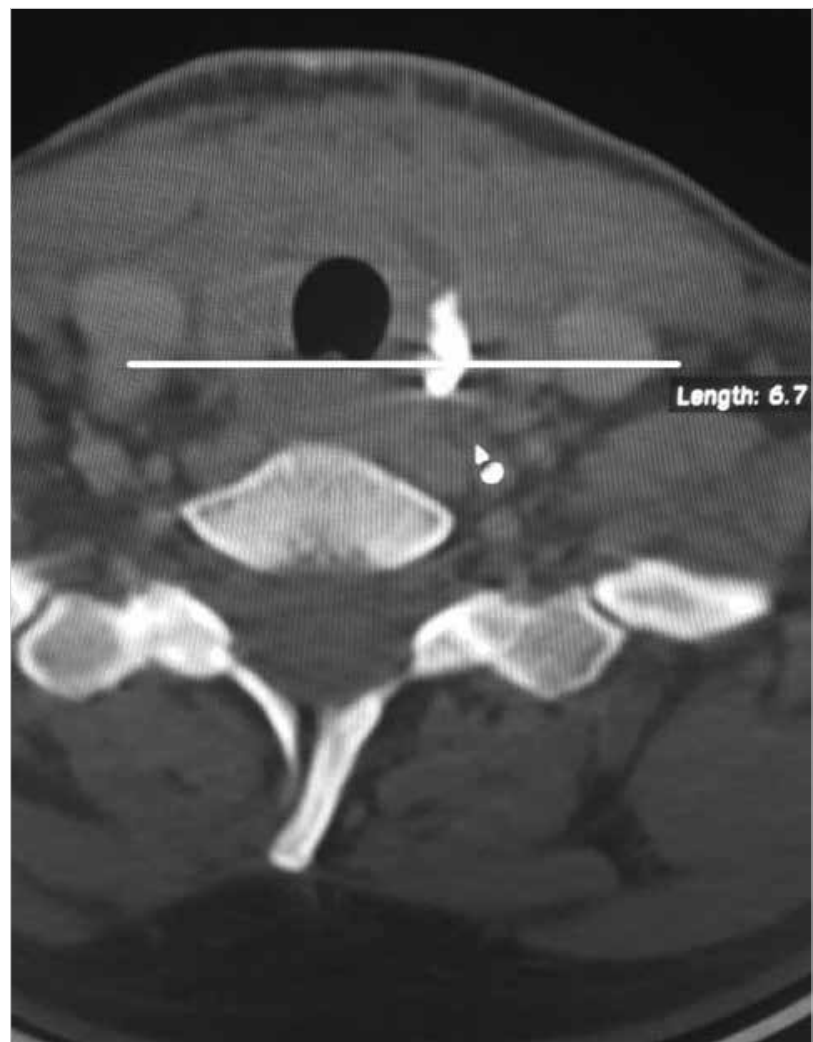

Figure 4. CT view of fistula tracts extending from the incisional line to the trachea

On CT, fistula tracts extending from the incision line to the trachea and both lobes of the thyroid gland were detected (Figure 3,4 ). The abscess was drained after opening the fistula tract under general anesthesia. The fistula tract was excised and the sutures causing foreign body reaction were extracted from both thyroid lobes adjacent to the trachea.

In the other patient treated surgically, differentiation of foreign body and recurrence could not be made by imaging techniques. The patient was operated with the suspicion of a foreign body. Abscess in the left lobe and 8 to 10 suture materials were detected in the same site, the area was cleaned.

\section{DISCUSSION}

Thyroidectomy is the most commonly performed endocrine operation in surgical clinics. One of the most common complications seen after thyroidectomy is bleeding. For this reason, all surgeons do their best to provide an effective bleeding control $(3,6)$.

Bleeding control is one of the indispensable factors of surgery. Ambroise Paré (the most important surgeon of the $16^{\text {th }}$ century who is accepted as the father of surgery in France) is the first physician to report that hemostasis could be easily achieved by vessel sealing $(7,8)$. Although this method has been introduced in the middle age, thyroid surgery has not been performed routinely until the 1900 s due to high bleeding rates (4).

Better vascular bleeding control has been achieved by the developments in surgical tools and techniques. Fundamental control have occurred especially due to new vessel sealing devices, which were introduced in the last decade. It has been reported that the endurance of these devices are equal to that of clips and knots if the devices were used in appropriate capacity $(4,9)$

In a questionnaire study on thyroid surgery and vessel sealing devices performed in our country, it was found that these devices are used in $65 \%$ of all thyroidectomy operations. In the same study, $47 \%$ of the surgeons reported that they use ligation in every case, while $55 \%$ stated that upper pole vessels must be ligated at least once (4).

Surgical ligation is achieved by using sutures. As it is known, all sutures are foreign bodies for the body and cause tissue reaction. Tissue reaction continues until the sutures are totally absorbed when an absorbable suture is used, while fibrous capsule formation is observed with the use of non-absorbable sutures. However, the body may sometimes develop an excessive reaction against this foreign body (10-12).

In our clinic, we use vessel sealing devices in the majority of dissection stages of thyroidectomy operations. However, we especially ligate upper pole vessels and structures close to the recurrent laryngeal nerve with sutures. In the previous years, non-absorbable silk sutures were used for ligating while absorbable sutures are currently being preferred. In our series, silk sutures have been used and the reactions occurred against silk. Similar cases have been reported in the literature. In the studies performed in our country, post-thyroidectomy suture reaction rate was determined as $0-1.3 \%$, while this rate was found as $2.1 \%$ in our study, being higher than that reported in the literature (13-15).

In the literature, the treatment methods used in these cases was unclear. In case of reaction, a chronic fistula usually develops and the suture material is removed from the tract spontaneously or by a minor surgical procedure. We usually perform such interventions under local anesthesia. However, surgical intervention was performed under general anesthesia in two cases due to the extensive and deep reaction in one of them and suspicion of a foreign body (sponge) in the other.

A suitable suture material should be easy to use, cheap and compatible with the tissue with a minimal tissue reaction. However, a suture material meeting all these criteria is yet not present. Silk is a proteinous material produced by silkworm. Therefore, it causes a significant inflammation in tissues. For this reason, it should be remembered that reaction may develop against silk suture material $(16,17)$.

Vessel sealing systems and ligation techniques with conventional sutures may be used in the dissection stages of thyroidectomy. Many studies in the literature have compared these two techniques, and no superiority has been detected in terms of efficiency. However, some studies indicated superiority of vessel sealing systems in terms of operation time as compared to conventional hemostasis techniques in thyroid surgery, with no detriment to safety outcomes (18). Sutures with a low risk for reaction and especially absorbable sutures should be preferred especially for upper pole ligation, as in our practice. 


\section{CONCLUSION}

Vessel sealing systems or classical suturing may be used during dissection in thyroidectomy. Development of suture reaction should be considered when suturing is preferred. It must be remembered that suture reaction may develop in conventional suturing. In such a condition, conservative treatment should be the primary choice.

Ethics Committee Approval: Authors declared that the research was conducted according to the principles of the World Medical Association Declaration of Helsinki "Ethical Principles for Medical Research Involving Human Subjects". (amended in October 2013).

Informed Consent: Written informed consent was obtained from patients who participated in this study.

Peer-review: Externally peer-reviewed.

Author Contributions: Concept - B.H.K., F.M.Y., S.E.; Design - B.H.K., M.B.B., F.M.Y., S.E.; Supervision - M.B.B., B.H.K., F.M.Y.; Resource - M.B.B., F.M.Y., B.H.K., Ö.A., H.B.A.; Materials - F.M.Y., B.H.K., Ö.A., H.B.A.; Data Collection and/or Processing - F.E., A.A., Ö.A., H.B.A.; Analysis and/or Interpretation - B.H.K., M.B.B., F.M.Y.; Literature Search - A.A., Ö.A., F.E., M.B.B., Writing Manuscript - B.H.K., M.B.B., S.E.; Critical Reviews - F.M.Y., S.E., B.H.K., M.B.B.; Other - A.A., Ö.A., H.B.A.

Conflict of Interest: No conflict of interest was declared by the authors.

Financial Disclosure: The authors declared that this study has received no financial support.

\section{REFERENCES}

1. Fong ZV, Rosato EL, Lavu H, Yeo CJ, Cowan SW. Emil Theodor Kocher, M.D., and his Nobel Prize (1841-1917). Am Surg 2012; 78: 1322-1324.

2. Cernea CR, Brandão LG, Hojaij FC, De Carlucci D, Montenegro FL, Plopper C, et al. How to minimize complications in thyroid surgery? Auris Nasus Larynx 2010; 37: 1-5. [CrossRef]

3. Sözen S, Emir S, Alıcı A, Aysu F, Yıldız F, Aziret M, et al. Complications after thyroidectomy and the affecting factors related with the surgeon. Turk J Surg 2010; 26: 13-17. [CrossRef]

4. Mayir B, Bilecik T, Ensari CÖ, Yardımcı EC, Oruç MT. The approach of general surgeons to the use of vessel sealing device in thyroid surgery. Turk J Surg 2014; 30: 197-200. [CrossRef]

5. Mourad M, Rulli F, Robert A, Scholtes JL, De Meyer M, De Pauw L. Randomized clinical trial on Harmonic Focus shears versus clamp-and-tie technique for total thyroidectomy. Am J Surg 2011; 202: 168-174. [CrossRef]

6. Huang $C F$, Jeng $Y$, Chen KD, Yu JK, Shih CM, Huang SM, et al. The preoperative evaluation prevent the postoperative complications of thyroidectomy. Ann Med Surg 2014; 4: 5-10. [CrossRef]

7. Kiter E. Frontiers of Spinal Surgery: Ambroise Paré. The Journal of Turkish Spinal Surgery 2010; 21: 391-394.

8. Ambroise Paré in Encyclopedia of World Biography. Eds; Byers PK, Bourgoin SM. $2^{\text {nd }}$ Ed. Gale Group, 2005, USA.

9. Zanghì A, Cavallaro A, Di Vita M, Cardì F, Di Mattia P, Piccolo G, et al. The safety of the Harmonic ${ }^{\circledast}$ FOCUS in open thyroidectomy: a prospective, randomized study comparing the Harmonic ${ }^{\oplus}$ FOCUS and traditional suture ligation (knot and tie) technique. Int J Surg 2014; 12 Suppl 1: 132-135. [CrossRef]

10. Yaltirik M, Dedeoğlu K, Bilgiç B, Koray $M$, Ersev H, Issever $\mathrm{H}$, et al. Comparison of four different suture materials in soft tissues of rats. Oral Dis 2003; 9: 284-286. [CrossRef]

11. Mallon WJ, Seaber AV, Urbaniak JR. A comparison of absorbable and nonabsorbable sutures to vascular response in immature arteries. J Reconstr Microsurg 1986; 2: 87-92. [CrossRef]

12. Lazard DS, Sebagh M, Legagneux J, Vignes JL, Masquelet AC, Chabolle F. Tracheal anastomosis: Monofilament absorbable suture versus monofilament non-absorbable suture. Experimental study in rats. Ann Otolaryngol Chir Cervicofac 2004; 121: 156160. [CrossRef]

13. Yabanoğlu H, Aydoğan C, Sahillioğlu E. Evaluation of 213 thyroidectomy cases: Hakkari experience. Turk J Surg 2011; 27: 212-215. [CrossRef]

14. Yorgancılar E. Surgical treatment of benign nodular goiter; report of 72 patients. Dicle Medical Journal 2009; 1: 35-38

15. Aydın S, Taşkın Ü, Koçak HE, Özdamar K, ŞentürkT, Güntekin B, et al. The impact of pressure dressing on post-thyroidectomy hypocalcemia: prospective randomized controlled clinical study. Turk Arch Otolaryngol 2014; 52: 57-60. [CrossRef]

16. Imperiale L, Marchetti C, Salerno L, ladarola R, Bracchi C, Vertechy $\mathrm{L}$, et al. Nonabsorbable suture granuloma mimicking ovarian cancer recurrence at combined positron emission tomography/ computed tomography evaluation: a case report. J Med Case Rep 2014 8: 202. [CrossRef]

17. RW Postlethwait, D A Willigan, A W Ulin. Human tissue reaction to sutures. Ann Surg 1975; 181: 144-150. [CrossRef]

18. Contin P, Goossen K, Grummich K, Jensen K, Schmitz-Winnenthal $\mathrm{H}$, Büchler MW, et al. ENERgized vessel sealing systems versus CONventional hemostasis techniques in thyroid surgery--the ENERCON systematic review and network meta-analysis. Langenbecks Arch Surg 2013; 398: 1039-1056.[CrossRef] 